\title{
Generating Goodwill and Friendliness in Attic Forensic Oratory*
}

\author{
Ed Sanders
}

\begin{abstract}
The pseudo-Aristotelian Rhetoric to Alexander accords arousal of jurors' goodwill a significant role in forensic argumentation. Aristotle, whose Rhetoric discusses friendship, seems to agree. While Aristotle sees conceptual differences between eunoia and philia, these are not reflected in the Attic corpus. There differences are semantic: the two words are used in some similar, but also some different, contexts. Orators sometimes explicitly request goodwill, normally in their prologues, and there appear to be patterns in which types of speech (public/private, prosecution/defense) or legal case see these requests. Orators also regularly protest their eunoia or philia for the city, in an attempt to prompt reciprocal good feeling. More wide-ranging are covert attempts to arouse goodwill/ friendliness through claims of a variety of good character traits, or through a description of the speaker's past actions and way of life.
\end{abstract}

\section{Rhetoricians on goodwill}

It is well known that emotional arguments are commonplace in oratory. As early as $422 \mathrm{BCE}$, contemporary with the earliest surviving Attic speeches, ${ }^{1}$ appeals to emotion were common enough to be satirized in Aristophanes' Wasps: Kleon enjoins jurors to turn up with three days'

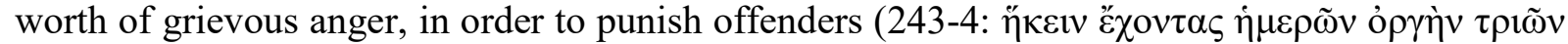

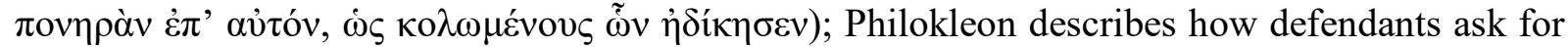

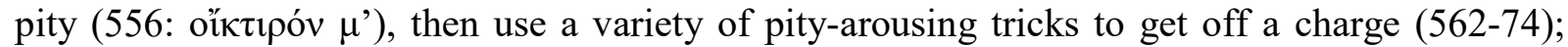
many of these are subsequently deployed in the mock trial of the dog Labes (975-8). Supporting evidence for these tricks is found in a lawcourt speech, in which the speaker says: 'I see that if somebody brings forward his children and weeps and laments, you take pity on the children ...

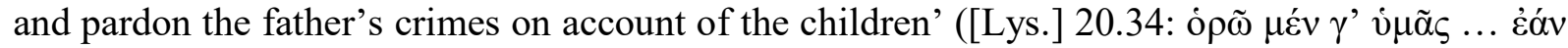

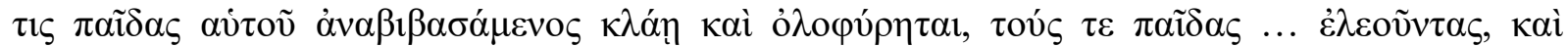

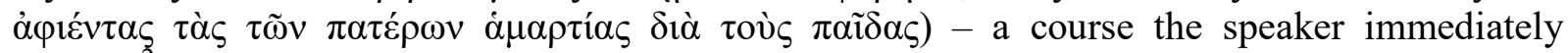
follows. ${ }^{2}$

Aristotle, in his Rhetoric, ${ }^{3}$ dismisses such tricks as having nothing to do with the facts and being merely an appeal to the juror $(1.1,1354 \mathrm{a} 16-18)$; however, he advocates emotional arguments that do relate to the case. He says that there are three modes of persuasion: rational argument (logos), arguments from character (êthos), and 'putting the audience into a certain

\footnotetext{
* I would like to express my heartfelt thanks to David Konstan, whose advice and support I have more than occasionally benefited from, and whose scholarship on emotions has greatly influenced both the subject and content of my own research. I should also like to thank the Leverhulme Trust for funding the research project from which this chapter derives, and Lene Rubinstein for her generous comments and suggestions on an earlier draft.

${ }^{1}$ The Attic oratorical corpus is a collection of works that survive from Classical-period Athens, specifically c. 420322 BCE. It includes 105 forensic (courtroom) speeches (see note 24), sixteen deliberative (Assembly) speeches, and four epideictic (display) speeches, as well as some tracts (written for publication, not oration), letters, example deliberative prologues, and rhetorical exercises.

2 Tr. Todd 2000: 226-7, slightly amended. Todd dates this speech to 410-409 (217).

${ }^{3}$ Kennedy 2007: 18 dates this treatise to $355-323$.
} 


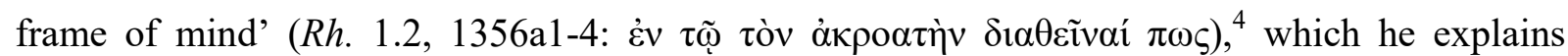

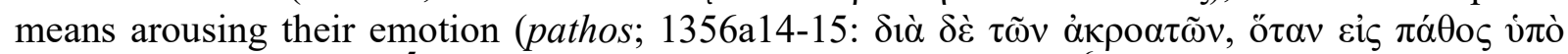

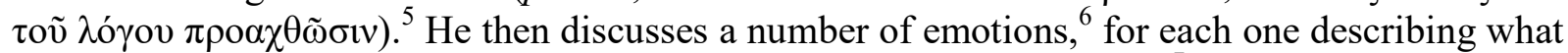
sort of person feels it, against whom it is felt, and in what circumstances. ${ }^{7}$

Aristotle does not tell us which emotions are important in which kinds of speeches, but the pseudo-Aristotelian Rhetoric to Alexander, ${ }^{8}$ describing forensic oratory, says:

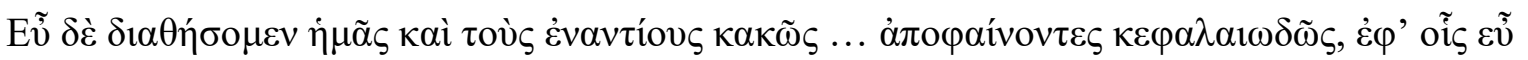

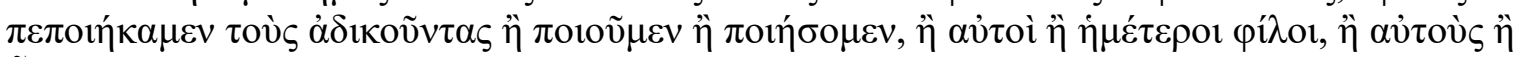

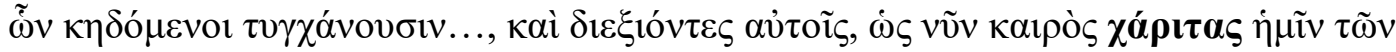

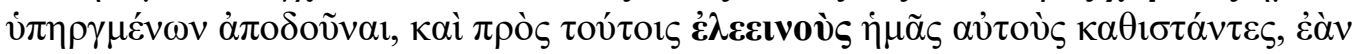

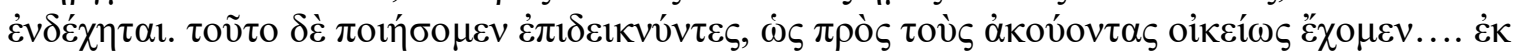

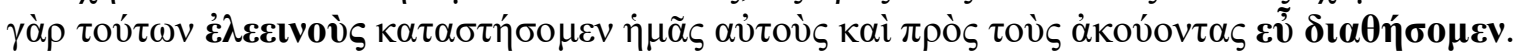

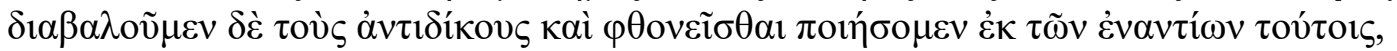

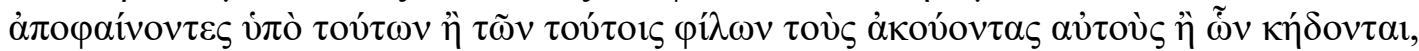

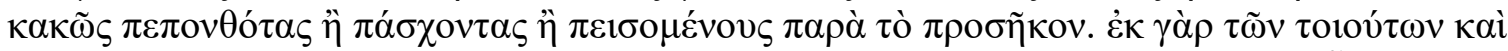

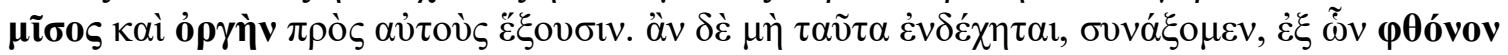

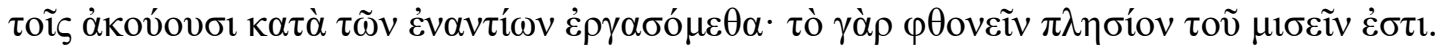

We shall dispose them favourably to ourselves and unfavourably to our opponents if ... we show briefly how we ourselves (or our friends) have benefited or are benefitting or will benefit those who are now seeking to wrong us (or those for whom they care); and point out to them that now is the opportunity to show us gratitude for our good services; and also, when it is possible, to make ourselves pitiable to them. This we shall do by showing that a close tie binds us to our hearers.... For it is by these means that we shall win pity and gain the goodwill of our audience.

We shall cause a prejudice and feelings of envy against our opponents by employing the opposite method and pointing out that our hearers, or those for whom they care, have received undeserved ill-treatment, or are receiving it, or are likely to receive it at the hands of our opponents or their friends; for by such arguments they will be induced to entertain feelings of hatred and anger against them. Where this is impossible, we shall collect together all the arguments by which we can create in our hearers a feeling of envy against our opponents; for envy is very near to hatred. ${ }^{9}$

\footnotetext{
${ }^{4}$ Tr. Rhys Roberts 1984: 2155.

${ }^{5}$ I refer to these respectively as logos, êthos, and pathos arguments. As we shall see, an argument can belong to more than one of the three categories.

${ }^{6}$ Rh. 2.2 on anger (orgê) and 2.3 on calming down (praünsis); 2.4 on friendship (philia) and hatred (misos); 2.5 on fear (phobos) and confidence (tharsos); 2.6 on shame (aischunê) and shamelessness (anaischuntia); 2.7 on gratitude (charin echein) and ingratitude (acharistein); 2.8 on pity (eleos); 2.9 on indignation (nemesan); 2.10 on envy (phthonos); and 2.11 on emulation (zêlos) and scorn (kataphronêsis). This is an idiosyncratic list: a) calming down, shamelessness, and ingratitude seem less emotions than a dissipation or lack of emotion; b) hope and pride (in particular) are ignored, though arguments arousing these emotions are frequently seen in deliberative oratory - see Sanders forthcoming.

${ }^{7}$ He says one must consider these for anger, 'and just the same for the other emotions' (Rh. 2.1, 1378a22-26).

${ }^{8}$ Probably written by Anaximenes, and dated by Chiron 2002: xl, cvii between 344/3 and 300 BCE.

${ }^{9}$ [Arist.] Rh. Al. 36, 1444b35-45a19; tr. Forster 1984: 2311-2, slightly amended.
} 
Pseudo-Aristotle is here talking about the peroration (epilogos) of the speech, in which we must 'dispose our judges to be favorable towards ourselves and unfavorable to our opponents' (36, 1444b28-30; cf. 1445a26-27), though he says these are reiterations of what should have been said throughout. He recommends earlier, regarding the prologue (prooimion):

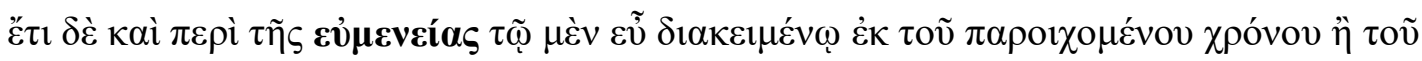

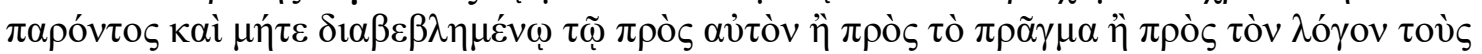

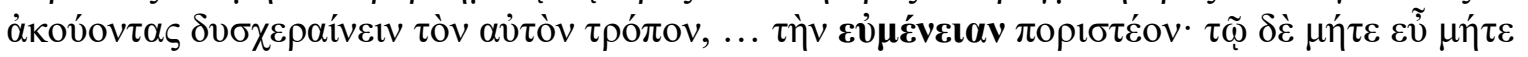

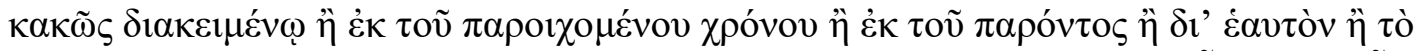

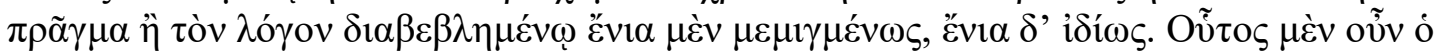

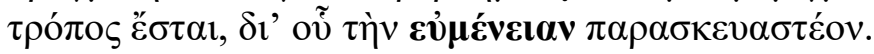

[A]s regards the goodwill of the audience, for someone they are well-disposed towards in connexion with either the past or in the present and have not been set at variance with because they are irritated with him or his action or his speech, we must secure their goodwill.... For someone they are neither well nor ill-disposed towards in connexion with either the past or in the present, or for someone they have been set at variance with because of his personality or his action or his words, we must [bring forward reasons for goodwill towards him,] sometimes blending them together, and sometimes taking them separately. Such then is the method by which we must conciliate goodwill. ${ }^{10}$

And elsewhere, talking about deliberative oratory, he says when urging help for some city we should bring forward reasons for feeling friendship and gratitude and pity (Rh. Al. 34, 1439b17:

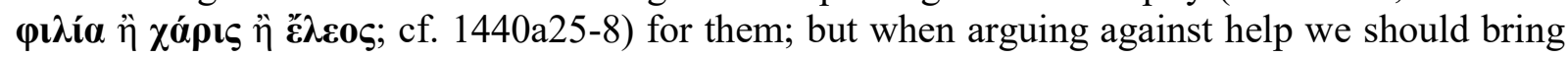

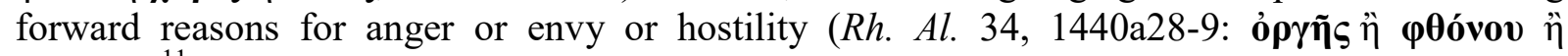
है $\chi$ $\theta$ pas). ${ }^{11}$

These passages present a consistent picture: that the speaker should create ill-feeling against his opponent by arousing anger, hatred, and envy for him; and good-feeling for himself by arousing pity, gratitude, ${ }^{14}$ and one other emotion that is variously described as 'being well disposed' (eu diatithenai), goodwill (eumeneia), or friendship (philia). ${ }^{15}$ A fourth term, which pseudo-Aristotle does not use but which is widespread in the Attic corpus, is eunoia - also usually translated 'goodwill'. 16

${ }^{10}$ [Arist.] Rh. Al. 36, 1441b36-42a7; tr. Forster 1984: 2306, somewhat amended.

${ }^{11}$ In Sanders forthcoming I argue that these emotions are mainly relevant to deliberative speeches that are quasiforensic, i.e. when a judgment is sought - and this assumes the city deliberating has the power to judge. In the vast majority of deliberative speeches - both in the Attic corpus and in Thucydides - emotions primarily aroused are fear (particularly), hope, confidence, contempt, shame, pride, and (in Thucydides) desire.

${ }^{14}$ Significant research has been published on arousal of these first five emotions in forensic oratory. On anger: Allen 2000: and 2003; Rubinstein 2004: and 2014; Sanders 2012. On hatred: Kurihara 2003; Rubinstein 2004; Sanders 2012. On envy: Fisher 2003; Cairns 2003; Sanders 2012 and 2014: 79-99. On pity: Johnstone 1999: 109-25; Bers 2009: 77-98; Rubinstein 2014. On gratitude: Rubinstein 2000: 212-31.

15 Though not made explicit, he should also suppress any bad feelings the opponent aroused against him, and good feelings the opponent aroused for himself.

${ }^{16}$ De Romilly 1958: 92: 'Eunoia, in Greek, is something more than good will: it means approval, sympathy and readiness to help. Having such meanings, it soon came to be applied to politics in a number of ways, as describing one's feeling towards a person, or a party, or the city...' Cf. my 'Reciprocal goodwill' section below. 
Pseudo-Aristotle seems to use these terms more or less interchangeably. Aristotle includes philia within his list of emotions aroused through pathos arguments (see note 5 above), but does not include eunoia (or eumeneialeu diatithenai). ${ }^{17}$ He sees a conceptual difference between the two, though, as he explains in the Nicomachean Ethics:

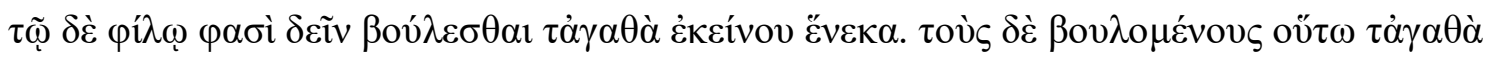

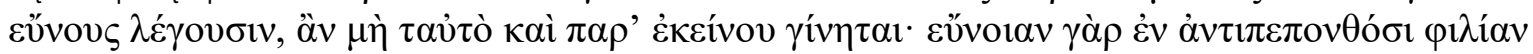
عĩval.

To a friend, however, it is said, you must wish goods for his own sake. If you wish good things in this way, but the same wish is not returned by the other, you would be said to have [only] goodwill for the other. For friendship is said to be reciprocated goodwill. ${ }^{18}$

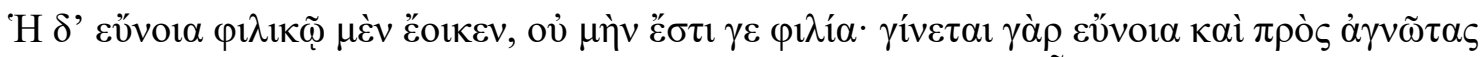

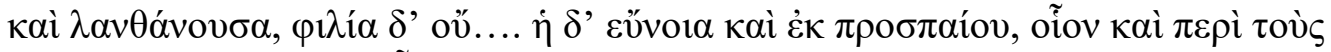

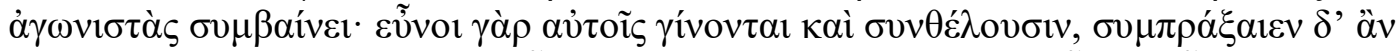

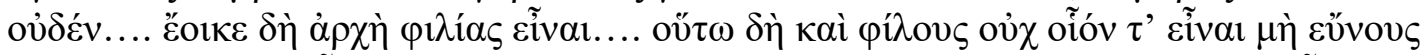

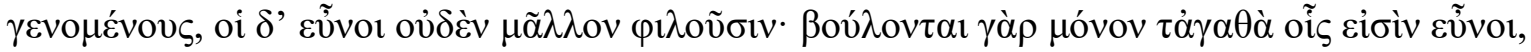

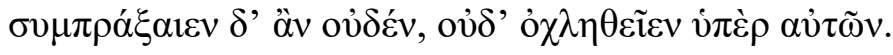

Goodwill would seem to be a feature of friendship, but still it is not friendship. For goodwill arises even toward people we do not know, and without their noticing it, whereas friendship does not.... [G]oodwill can also arise in a moment, as it arises, for instance [in a spectator] for contestants. For [the spectator] acquires goodwill for them, and wants what they want, but would not cooperate with them in any action.... It [goodwill], then, would seem to be the beginning of friendship.... [T] hough people cannot be friends without previous goodwill, goodwill does not imply friendship; for when they have goodwill, people only wish good things to the other, and will not cooperate with him in any action, or go to any trouble for him. ${ }^{19}$

For Aristotle, goodwill is thus a one-way feeling, while friendship is reciprocal, ${ }^{20}$ and the former may (but need not) lead to the latter. We can compare these passages with one in the Rhetoric:

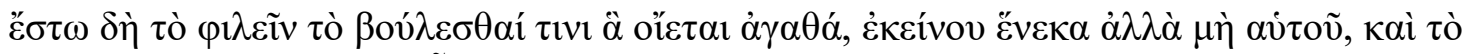

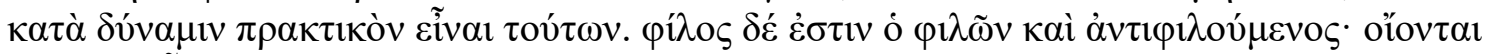

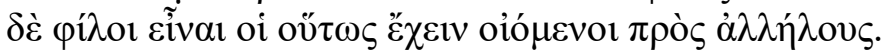

We may describe friendly feeling towards anyone as wishing for him what you believe to be good things, not for your own sake but for his, and being inclined, so far as you can, to bring

\footnotetext{
${ }^{17}$ We shall see below that he does make goodwill relevant to êthos arguments.

${ }^{18}$ Arist. Eth. Nic. 8.2, 1155b31-4; tr. Irwin 1999: 121.

${ }^{19}$ Arist. Eth. Nic. 9.5, 1166b30-67a10; tr. Irwin 1999: 143, slightly modified.

${ }^{20}$ Hadreas 1995 persuasively argues that Aristotle sees goodwill as cognitive (like other emotions) rather than volitional: it is a judgment of someone's worthiness of good regard, rather than a choice to treat someone well. Price 1989: 148-61 for further on the relationship of eunoia and philia in Aristotle.
} 
these things about. A friend is one who feels thus and excites these feelings in return. Those who think they feel thus towards each other think themselves friends. ${ }^{21}$

In this passage Aristotle seems to describe the one-way feeling, called eunoia in the Ethics, with the verbal noun to philein; other parts of the verb and the substantive philos are used for the reciprocal feeling.

A survey of the Attic corpus, though, reveals a rather different picture from these theoretical discussions. In surviving forensic speeches, no speakers ask for the jury to eu diatithenai them, and their eumeneia is sought only once. ${ }^{22}$ Philia is sought a number of times indirectly, though it is never directly requested. By far and away the most common of these emotions in the oratorical corpus is eunoia. Eunoia and philia are thus our two key terms. In the Attic corpus there does not seem to be a significant distinction between them: eunoia is normally sought (and always the emotion explicitly requested), philia appears as an occasional synonym, and both can be reciprocal.

\section{Requests for eunoia}

The most obvious evidence that an emotional response was sought in a speech is that the speaker explicitly asks for it. Requests for eunoia occur in twenty-one of the surviving 105 forensic speeches (i.e. $20 \%$ ), ${ }^{23}$ normally in a formulation such as 'Please listen to me with eunoia'. These are not evenly distributed: we find them in $6 \%(2 / 32)$ of public prosecutions, $16 \%(5 / 31)$ of private prosecutions; $32 \%(7 / 22)$ of public defenses; $40 \%(4 / 10)$ of private defenses; and $30 \%$ $(3 / 10)$ of adjudications. ${ }^{24}$ While the number of surviving speeches is low and therefore might not be wholly representative, these results still seem significant, ${ }^{25}$ and a closer look at the speeches allows us to draw some tentative conclusions as to when eunoia was - or was not - likely to be requested.

Both Aristotle (Rh. 3.19, 1419b10-19, 24-27) and pseudo-Aristotle (Rh. Al. 6, 1444b2045a26) advise that the peroration of a prosecution speech should include a condemnation of the

${ }^{21}$ Arist. Rh. 2.4, 1380b36-81a3; tr. Rhys Roberts 1984: 2200.

${ }_{22}^{2}$ Dem. 45.1. Twice, if one counts [Andoc.] 4.7, a rhetorical exercise.

${ }^{23}$ Andoc. 1.6 (twice) and 9; Lys. 16.9, 18.26, 19.11; Isae. 2.2, 6.2, 7.4, 8.5, 10.3; Dem. 18.1-10 (seven times!) and 199, 23.4, 27.3, 34.1, 35.5, 40.4, 45.1 and 85, 47.3, 57.1, 58.3; Aeschin. 2.1 and 7; Hyp. 1.19.

${ }^{24}$ Public prosecutions: request Dem. 23, 58 (total 2); no request Antiph. 1; Lys. 6, 12, 13, 14, 15, 22, 26, 27, 28, 29, 30, 31; Dem. 19, 20, 21, 22, 24, 25, 26, 53, 59; Aeschin. 1, 3; Hyp. 2, 5; Din. 1, 2, 3, Lycurg. 1 (total 30).

Public defense: request Andoc. 1; Lys. 16, 18, 19; Dem. 18; Aeschin. 2; Hyp. 1 (total 7); no request Antiph. 5, 6; Andoc. 2 (which I count as a defense speech for the purposes of this study, though it was delivered to the Assembly not to a court as part of a trial); Lys. 1, 3, 4, 5, 7, 9, 20, 21, 24, 25; Isae. 11; Hyp. 4 (total 15). Private prosecution: request Isae. 6; Dem. 27, 40, 45, 47 (total 5); no request Lys. 10, 32; Isoc. 17, 18, 20, 21; Isae. 3, 5; Dem. 28, 30, 31, 32, 33, 36, 37, 38, 39, 41, 44, 46, 48, 49, 50, 54, 56; Hyp. 3 (total 26). Private defense: request Isae. 2; Dem. 34, 35, 57 (total 4); no request Lys. 23; Isoc. 16; Isae. 12; Dem. 29, 52, 55 (total 6). Adjudication: request Isae. 7, 8, 10 (total 3); no request Lys. 17; Isae. 1, 4, 9; Dem. 42, 43, 51 (total 7).

${ }^{25}$ These proportions are fairly similar to explicit calls for pity - see Johnstone 1999: 118. They differ from calls for anger and hatred, which Rubinstein 2004 has shown appear mostly in public - with a significant minority in private - prosecution speeches, and are tied to calls for punishment (timôria, kolazein) rather than compensation. Rubinstein argues convincingly that they are generally sought when jurors can be presented as co-sufferers: i.e. that the crime affects the whole community. Cf. Aristotle, who says that orgê is a desire for

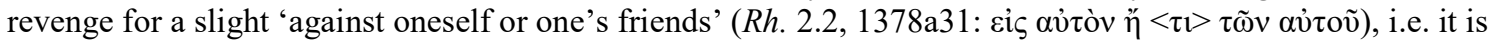
personal; and that whereas we are angry against those who offend against us, hatred is also [sc. as well as

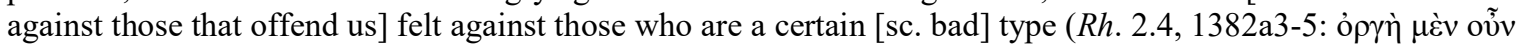

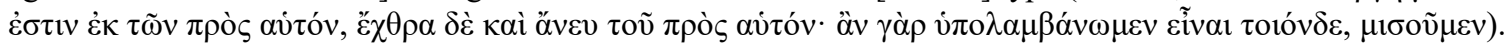


character and actions of the defendant, and an arousal of emotions - including good emotions for the prosecutor and hostile ones for the defendant (see above). Similarly, both recommend that a defendant's prologue should suppress any hostile emotions that have been aroused, and arouse good emotions for himself (Arist. Rh. 3.14, 1415a25-34; [Arist.] Rh. Al. 36, 1441b36-42a7; 1442a21-b27). ${ }^{26}$ Thus both rhetoricians imply that all speakers might attempt to arouse goodwill for themselves: prosecutors in the peroration, and defendants in the prologue. This is far from what we see in the Attic corpus: ${ }^{27}$ the choice whether or not to include these requests seems much more strategic.

In Classical Athenian trials the prosecutor spoke first, and (both according to the theorists as above, and seen in actual speeches) prosecutions frequently end with strong invective against the defendant, even a full 'character assassination'. Defendants thus always started on the back foot, since the jury would have been biased against them before they even stood up. ${ }^{28}$ This suggests why we are far more likely to find requests for goodwill at the start of defense speeches. However, we do not find them uniformly in defense speeches. There are two general reasons that account for this in some cases. One is that some speeches are missing prologues, or have shortened ones - possibly an accident of survival, possibly because only part of the speech was commissioned from the speechwriter - and so if there had been a plea for goodwill it has not been preserved. The second is that a number of speeches are given by sunêgoroi (supporting speakers), ${ }^{29}$ and these are less likely to contain pleas for goodwill, as it would not normally be the supporting speaker himself who had suffered the character assassination. ${ }^{30}$ Even allowing for these issues, we find prosecutions containing calls for eunoia, and defense speeches with prologues intact and spoken by the actual defendant that do not have such calls. We must therefore look more closely at the circumstances surrounding individual trials - these might include the individuals involved, their previous relationship with each other, previous judicial contact with the demos, or in some cases the nature of the crime or type of legal case itself.

We saw above that in the Attic corpus private prosecutions only rarely, and public prosecutions almost never, include a request for eunoia (Aristotle and pseudo-Aristotle are thus both wrong on this point). At least for public prosecutions, the ho boulomenos aspect of many of these cases would obviate the point of a call for goodwill: ${ }^{31}$ prosecutors ostensibly act as the agent of the demos, prosecuting someone who has offended against the entire community, ${ }^{32}$ and so do not need to ask for its goodwill. This is not the case for private prosecutions, but (as mentioned above) there would have been no invective-filled speech before they rose, and so no particular need to ask for goodwill. There are seven prosecution speeches in which we do find calls for goodwill (see note 24), and in a number of these we can find particular reasons for them.

\footnotetext{
${ }^{26}$ See further below on the role of eunoia in prologues.

27 Though admittedly no rhetorical argument (logos, êthos, or pathos) is made universally.

${ }^{28}$ Indeed in [Dem.] 45.6, the speaker claims that on a previous occasion the prosecutor had so persuaded the jury with lies, that they refused to even let him speak in reply. If true, then it was unlikely to have been a unique instance.

${ }^{29}$ On which see Rubinstein 2000.

${ }^{30}$ The exceptions are Isae. 2 and 6, and Dem. 18. In the last of these the speaker Demosthenes, rather than the nominal defendant Ktesiphon, was in fact the target of the prosecutor's attack. On Isae. 6, see main text below.

${ }^{31}$ Most public prosecutions could be brought by any citizen who wished (ho boulomenos) - see MacDowell 1978: 53-62; Todd 1993: 91-4. Some, however, could only be brought by a public official acting ex officio, e.g. an euthuna (investigation of performance of public office) - see MacDowell 1978: 170.

32 e.g. proposing an illegal decree: Dem. 22, 24, Aeschin. 3, Hyp. 2; working with the oligarchic junta: Lys. 12, 13, 31; embezzlement: Lys. 27, 28, 29; bribe-taking: Hyp. 5, Din. 1, 2, 3; desertion: Lys. 14, Lycurg. 1; crimes of religious pollution: Antiph. 1 (homicide), Lys. 6 (blasphemy).
} 
Dem. 27 is a prosecution brought by Demosthenes himself shortly after reaching his majority, in an attempt to recover his father's estate from his guardians. Athenian juries were regularly sympathetic towards orphans, ${ }^{35}$ and Demosthenes makes use of this. His request for eunoia is followed by two arguments: an attempt to arouse hostility for his opponents as able

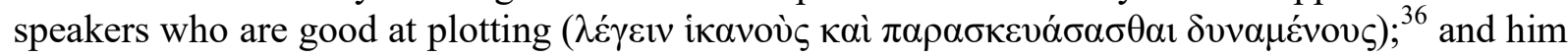
being young and inexperienced (27.2). A plea for eunoia is followed by attempts to arouse hostility for opponents in nine other speeches too, ${ }^{37}$ comprising almost half of all speeches containing calls for eunoia, so 'feel goodwill for me because my opponent is a rascal' can be considered a common argument. The orphan issue crops up again in Isae. 6, from the other side: here the defendants include two orphans, and so the prosecutor may have felt obliged to counter any hostility that might be felt against him for bringing the case.

Another speech in which the speaker makes an issue of his age alongside a plea for eunoia is Dem. 58, a denunciation (endeixis) of one Theocrines for bringing prosecutions while a state debtor. The prosecutor is a young man, acting for his father (who cannot prosecute, being disenfranchised after an earlier prosecution by Theocrines). It would be unusual for someone not yet involved in politics to bring this case, so the speaker goes out of his way to ask for eunoia on the grounds that he is acting in obedience to his father, he is young and without experience, ${ }^{38}$ and because he has been betrayed and abandoned by his co-prosecutors, who were bought off by Theocrines (58.3-4).

One other category of prosecution that is several times linked to calls for eunoia (Isae. 6; Dem. 45, 47) is a dikê pseudomarturiôn - a case against false witnesses. In these trials, Athenians had already delivered a verdict against the plaintiff and therefore would probably be hostile, in the first instance, to them coming back for another 'bite at the cherry' ${ }^{39}$ This might suggest why several such cases contain these pleas (though, admittedly, others do not).

In defense speeches and adjudications, we find requests for eunoia with some regularity. Here the type of action appears to be an important factor. In public actions, we do not see pleas where the case involves homicide or premeditated violence (Antiph. 5, 6; Lys. 1, 3, 4), or crimes against the dêmos - e.g. treason (Hyp. 4), taking bribes/embezzlement (Lys. 21), or taking part in oligarchic regimes ([Lys.] 20, Lys. 25). Religious offences are more mixed: Lys. 7 and Andoc. 2 (which I am considering as quasi-forensic - see note 24) do not include requests for eunoia; Andoc. 1 does. It is likely that, alongside other serious crimes, these would not normally include such a plea; but we can note that two very long speeches which include a lengthy defense of one's life (Dem. 18; Aeschin. 2) do include such pleas near the start, and it is possible the length of Andoc. 1 induced him to include it. Lys. 16 also includes a plea for eunoia before similarly embarking on an (albeit shorter) account of his actions over many years. ${ }^{40}$

In private defense cases and adjudications, we find that inheritance cases frequently allow such pleas - e.g. three of Isaeus's six adjudications include a call for eunoia ${ }^{41}$ significantly higher than the rate of other defense/adjudication speeches - and this higher likelihood might be

\footnotetext{
${ }^{35}$ See Rubinstein 2014: 140-8.

${ }^{36}$ See Sanders 2012: 373-4 on sophistic cleverness and facility at speaking arousing hostility.

${ }^{37}$ Isae. 2.2, 7.4, 8.5, 10.1 - the last with an almost identical phrase; Dem. 23.4, 40.4, 45.1, 47.3, 57.1.

${ }^{38}$ A speaker also asks for eunoia for this reason at Dem. 34.1.

${ }^{39}$ See note 28 on [Dem.] 45, in which the speaker had a slave background - also unlikely to endear him to the dêmos.

${ }^{40}$ Lys. 23 is a private defense speech including an account of the speaker's father's life, though it appears to be missing a prologue, which perhaps explains why no request for eunoia is seen.

${ }^{41}$ See note 24. Johnstone 1999: 118 shows that inheritance cases also frequently contained pleas for pity.
} 
because of the complicated nature of these cases: a polite attempt to build an emotional connection could help to compensate for the increased attention required to follow a complicated history. Outside inheritance cases, disputes over money do not tend to see requests for eunoia (e.g. Lys. 17; Dem. 29, 42, 52, 55; though Dem. 35 includes one) - possibly reflecting the lower likelihood of sympathy from mostly poor jurors. A dispute over a trierarchic crown (Dem. 51) is perhaps also seen as too trivial to gain emotional support; but one over grain (Dem. 34) might be sufficiently relatable-to by poorer jurors that a request for eunoia is seen. A dispute in which the defendant stands to lose his citizenship (Dem. 57) also contains a plea for goodwill. ${ }^{42}$

Almost all pleas for eunoia occur near the beginning of the speech (see note 21), in the prologue. ${ }^{43}$ This, contra the rhetoricians, applies as much to prosecution as defense speeches. Prologues primarily set the scene and explain why the case is being brought/defended (Arist. $R h$. 3.14, 1415a22-24; [Arist.] Rh. Al. 36, 1441b32-34), but their functions also include arousing goodwill - labelled captatio benevolentiae by later rhetoricians. ${ }^{44}$ Stephen Usher has listed the ways speakers do this: they might flatter the jury by 'expressing confidence in their fairmindedness', or sympathize with their task; a speaker might mention his inexperience in speaking, his disadvantages (e.g. poverty), or his 'retiring, non-litigious disposition'. ${ }^{4}$

So far we have discussed only explicit calls for eunoia, but this is only one - if an important - oratorical technique. Many types of case deter explicit exhortation to feel emotions. ${ }^{46}$ Furthermore, explicit calls for emotion are not simply inserted with no link to the surrounding argument; rather they are built up to, subsequently explained, or arise out of narrated circumstances. Aristotle does not tell an orator to call for emotions, but to show the audience that certain situations exist so emotions will arise naturally. ${ }^{47}$ Such covert methods of emotion arousal have received far less attention from scholars, yet they are far more ubiquitous and diverse than explicit exhortations. And unlike explicit calls for eunoia, its covert arousal can occur anywhere in the speech. In the remainder of this chapter, I shall concentrate on covert arousal of goodwill. One particular method is by the speaker stating his own goodwill (or opponent's lack of it) for the dêmos, which I shall argue is intended to generate reciprocal goodwill (or not) in return. Other methods involve the speaker describing his character (or otherwise labelling himself), or his past actions and way of life.

\footnotetext{
${ }^{42}$ Isoc. 16 is also a defense in a matter of citizenship, but it is missing its prologue so we do not know if the speaker asked for goodwill.

${ }^{43}$ This is not unique to oratory. Goldberg 1983 argues that Terence uses oratorical models in seeking an audience's goodwill when trying to capture attention at the start of a play. Chiron 2011 says the prologue of the Greek novel Daphnis and Chloe includes a quasi-oratorical attempt to capture 'une disposition favorable' (258) in the audience (i.e. reader). Conversely Earl 1972: 844, following Lucian Hist. 53, states that the 'appeal for a favorable hearing' is not part of the historiographical prologue.

${ }^{44}$ See Fortenbaugh 1988 on Cic. De orat. 2.178-216.

${ }^{45}$ Usher 1999: 22-3, drawing here solely on Antiphon and evidence from tragedy and Old Comedy - by inference, all these techniques were known and available for use throughout the period covered by the Attic corpus. See also De Brauw 2010: 191-3.

${ }^{46}$ See note 25 re Rubinstein 2004 on calls for orgê/misos. See also Sanders 2014: 79-99, where I argue that the strong negative connotations of phthonos (envy) means the word is mainly used explicitly in oratory to allege motivation.

${ }^{47}$ E.g. a speech should prepare its audience to be angry, and show the opponents as the types one should be angry at, and as having done things that cause anger - see note 7 .
} 


\section{Reciprocal goodwill}

Aside from calls for eunoia, there is a second very frequent use of eunoia words in the corpus, and that is statements that the speaker does - or his opponent does not - feel eunoia, or sometimes philia, ${ }^{48}$ for the city. ${ }^{49}$ We can translate this as goodwill, but here the word implies loyalty/devotion to the city: i.e. patriotism (cf. note 16). Aristotle tells us that philia is reciprocal (see above),${ }^{50}$ and in the Attic corpus eunoia is used more or less synonymously with it (contra Aristotle). There are several instances in the corpus where eunoia's reciprocity is stated: Demosthenes, in On the Crown, asks the jury to have as much eunoia for his welfare as he

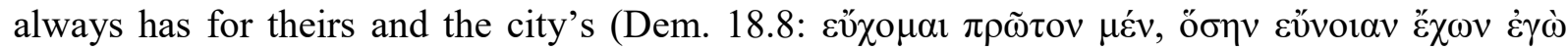

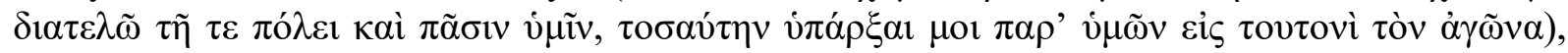
and later says those who achieve anything through eunoia should receive honour and kindness

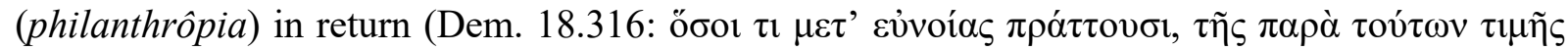

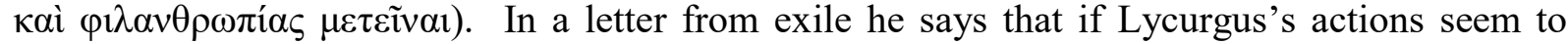
have been inspired by eunoia towards the demos, then his sons should receive good things and

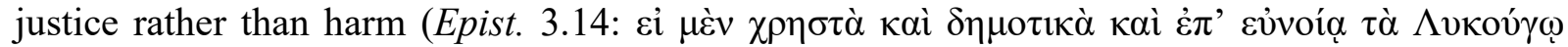

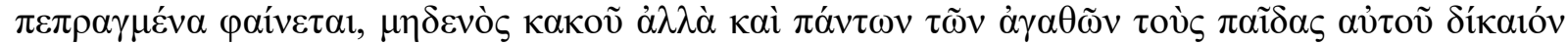

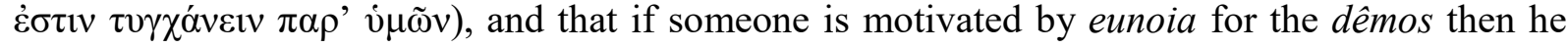

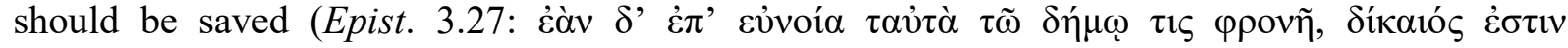
$\sigma \omega \dot{\omega} \zeta \varepsilon \sigma \theta \alpha \imath)$.

Lysias's Against Agoratos, prosecuting an informer who caused the deaths of several citizens during the oligarchic junta of 404-403 BCE, contains an extended example. Lysias begins: 'It is fitting, men of the jury, that you should all take vengeance on behalf of those who are dead,

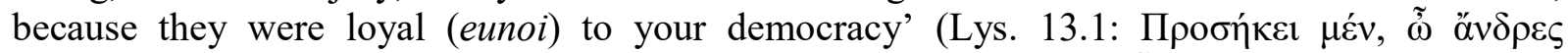

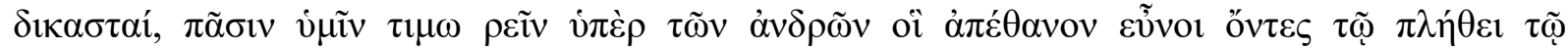
$\dot{v} \mu \varepsilon \tau \dot{\varepsilon} \rho()_{)}$. He later says that on dying, Agoratos's victims placed an injunction on all their

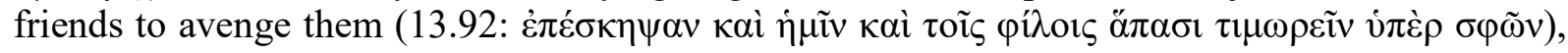
and if they did some service to the city or the democracy, then it must follow that all jurors are

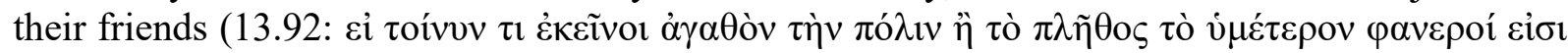

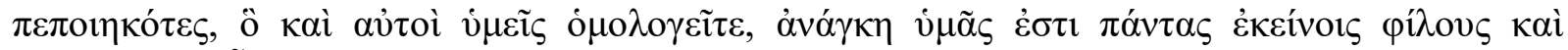

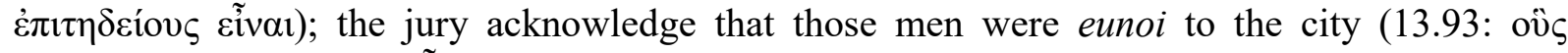

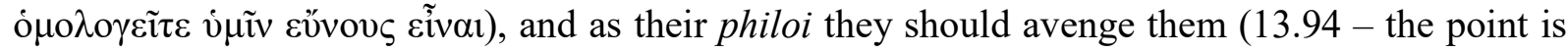
repeated at $\S \S 96-7)$. Such professions of eunoia are relatively common, and we should not doubt that they are intended to awaken reciprocal good feeling. ${ }^{51}$ Similarly, we sometimes find the opponent's eunoia for the city or dêmos denied, which we can infer aims to suppress reciprocal eunoia for them. ${ }^{52}$

\footnotetext{
${ }^{48}$ Especially in Lycurgus; this must be an idiosyncratic usage, as all his contemporaries prefer eunoia.

${ }^{49}$ In Aristotle's discussion of êthos arguments (see note 5), he includes eunoia as one of three character traits that make someone seem trustworthy (pistos; Rh. 2.1, 1378a6-15); and so presumably it assists persuasion.

${ }^{50}$ The reciprocity inherent in Greek friendship is widely accepted by scholars - see e.g. Foxhall 1998: 52-5, 65-7; Konstan 1997: 79-82 and 2006: 170; Mitchell 1997: 14-15; Herman 1987: 29-30, 60-1.

${ }^{51}$ Speaker's (or his client's) eunoia/philia for the city: Andoc. 2.25; Lys. 13.1 and 92-7 (six times), 16.3, 20.16; Dem. 18.110, 173, 286, 301, and 316-22 (five times), 42.32; Aeschin. 2.46, 118, and 181. Speakers' father's/ancestors' eunoia for the city: Antiph. 5.76 (twice); Andoc. 1.141; Lys. 10.27, 11.9; 18.3-8 (four times) and 19, 20.27; Isoc. 16.28 and 41 (twice).

52 Opponent's lack of eunoia/philia for the city: [Andoc.] 4.16; Lys. 14.10, 20.17, 22.11 and 13, 30.15, 31.13 and 18; Dem. 18.198, 276-81 (three times), and 291, 58.30; Aeschin. 3.17 and 246-8 (twice); Din. 1.102 (twice);
} 
One other word used to express loyalty/patriotism is prothumia, implying zeal on the city's behalf. Demosthenes shows the connection, saying that his efforts on behalf of the city showed both prothumia and eunoia (Dem. 18.286). ${ }^{53}$ Sometimes speakers say they (or relatives) fulfilled their liturgical obligations to the city with more prothumia than required, ${ }^{54}$ and the jury's prothumos assistance is once reciprocally requested (Lys. 18.25). The usual emotional response to excess liturgy performance is gratitude (charis), ${ }^{55}$ so this suggests the borderline where gratitude and goodwill shade into each other. A particularly striking call for charis in return for prothumia comes in Lysias's For Polystratos (20.30-1), that the jury might encourage others to be prothumoi in future so that they too might receive charis in return. While the emotion mentioned is charis rather than eunoia, it is in return for political advice and beyond-theordinary military services (rather than liturgies), and so this relates to Demosthenes' statement at 18.286. Despite the request being for charis, the similarity in how prothumia is used in this passage to the many where eunoia implies devotion, is strong evidence that such assertions could be expected to arouse reciprocal good feeling from jurors.

\section{Character and past actions}

How might a speaker arouse goodwill and friendly feeling without mentioning eunoia or philia at all? Once again, Aristotle points the way, in his discussion of philia/to philein:

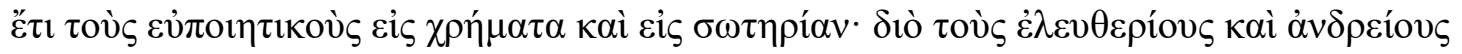

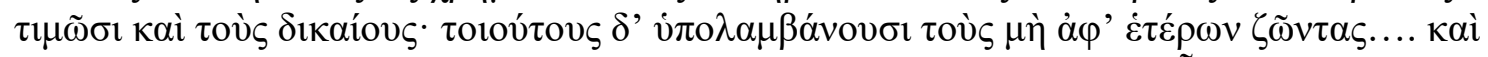

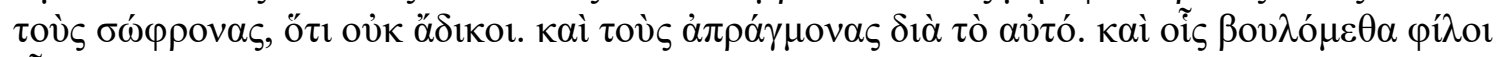

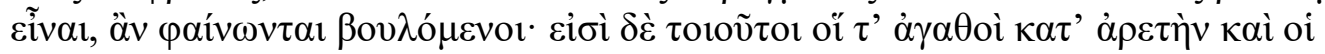

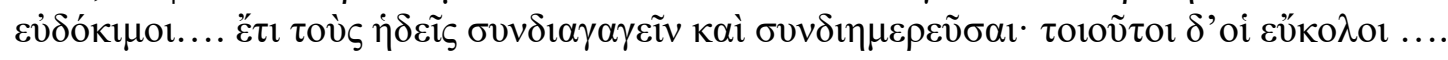

And also [people feel friendly] to those who are willing to treat them well where money or personal safety is concerned; and therefore we value those who are liberal and brave. And to just men - the just they consider to be those who do not live on others... They also like temperate men, because they are not unjust to others; and for the same reason, those who mind their own business. And also those whose friends we wish to be, if it is plain that they wish to be our friends: such are the good in respect of excellence.... And also those with whom it is pleasant to live and spend our days: such are the good-tempered.... ${ }^{56}$

And more succinctly in the Nicomachean Ethics: 'But in general goodwill results from some sort of virtue and decency, whenever one person finds another to be apparently fine or brave or

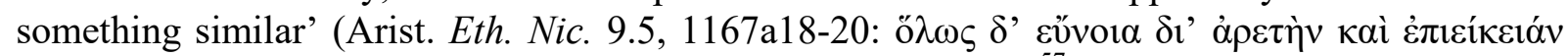

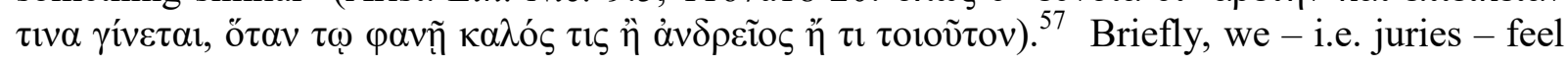

Lycurg. 1.71, 88, 100-3 (five times), and 133. Opponent's friendship for oligarchic faction, or loyalty to another city: Lys. 12.51, 14.19; Hyp. 2.17.

${ }^{53}$ Speakers' (or their relatives') prothumia for the city: Andoc. 2.13; Isoc. 18.65; Lys. 3.9, 12.99, 25.17 (twice); Isae. 7.37; Dem. 18.57, 110, 286, 301; opponent's prothumia for the city denied: Lys. 12.50.

${ }^{54}$ Lys. 7.31-2 (twice), 16.17, 18.7, 21.23; Dem. 38.26, 47.48, 49.46, 50.10. Opponent's lack of prothumia: Dem. 45.66.

55 See Ober 1989: 227-33.

${ }_{56}^{56}$ Arist. Rh. 2.4, 1381a19-30; tr. Rhys Roberts 1984: 2200, slightly modified.

${ }^{57}$ Irwin 1999: 144. 
goodwill/friendship for those who have one or more of the character virtues. ${ }^{58}$ Those mentioned here include justice (dikaiosunê), courage (andreia), liberality (eleutheriotês), temperance (sôphrosunê), excellence (aretê), good repute (eudoxia), and good temper (eukolia), and in Eth. Nic. 3-4 we also find magnificence (megaloprepeia), magnanimity (megalopsuchia), mildness (praotês), friendliness (philia), truthfulness, wit, and a proper sense of shame (the last few without Greek labels).

An important aspect of Aristotle's virtues is that each is a mean (mesotês) between two vices. This idea is also suggested by the word metrios - moderate - which appears many times in the Attic corpus, and is regularly lauded, connected to other virtues, or recommended to Athenians. Isocrates states in tracts that those who behave most appropriately are the most metrios (12.31), that metriotês and self-control (sôphrosunê) are preferable (7.4), that Athenians should choose to be metrios with justice (dikaiosunê, 8.93), and - in a lawcourt speech - that Athenians have metriotês (18.32). Similar comments appear in other orators. Young and old Athenians alike are metrioi ([Dem.] 25.88), and those most metrioi are those who advise best (25.93). The state fares best with metrioi in charge ([Dem.] 58.62). The friend of the people should be metrios (Aeschin. 3.170), though some politicians are not metrioi by character (tois tropois, Aeschin. 2.173 ) - said disapprovingly. Demosthenes recommends convicting Androtion to encourage everyone else to behave more moderately (22.68). Clearly metriotês is a good thing, so a speaker claiming that he (or his client) is moderate is surely claiming good character, and so seeking to encourage friendly feeling for himself. Such claims are seen many times in the corpus, ${ }^{59}$ and the opponent's metriotês is denied in many more. ${ }^{60}$ In one speech, the speaker connects metriotês to good feeling, saying that he and his friend are more eunous and metrios than their opponents (Isae. 1.29) - as usual a claim of eunoia being intended to arouse it. A speaker need not even claim to be metrios if his conduct demonstrates it: in Against Konon, the speaker Ariston says he could have prosecuted his opponent by a public suit for hubris, a charge which carried the death penalty; instead he chose to bring a private suit for battery, leading only to a fine (Dem. 54.2). ${ }^{61}$ This is clearly intended to generate goodwill.

A word with similar meaning is kosmios - orderly. Isocrates says in a lawcourt speech that it is good to make the citizens more kosmioi (20.18), and in tracts speaks favorably of kosmiotês alongside self-control (sôphrosunê; 7.37), and claims that the democracy is both just (dikaios) and orderly (7.70). Aeschines says that Solon wanted Athens's politicians to be orderly (3.3) the virtue is labelled eukosmia - and the laws enforce this (1.34); he says jurors' children should exhibit eukosmia (1.8), and that laws about it are most important as they lead to better run cities (1.22). Lysias twice has his speakers opine that if their opponents are convicted, others will be made more kosmioi $(22.19,27.7)$. Again, we can conclude that claims of kosmiotês in the corpus

\footnotetext{
${ }^{58}$ On êthos arguments in the Attic corpus, see Carey 1996. Although Aristotle characteristically splits êthos and pathos arguments (as does Carey), there is no reason why a particular argument cannot persuade in more than one way - and I believe that many do. While I make the narrow case here that some specific character traits aroused goodwill/friendly feeling in Classical Athens, I think it likely that character arguments will always have emotional ramifications: i.e. that humans everywhere will feel favorable to those they see as morally good, and hostile to those they see as morally bad.

${ }^{59}$ Isoc. 15.36 and 155 (the latter by inference); Isae. 7.39-40 (twice); Lys. 16.3; Dem. 18.10 and 321, 21.101 and 185, 24.6, 36.58, 42.12, 45.77, 54.15 and 24; Aeschin. 1.1 and 3, 2.181, 3.218.

${ }^{60}$ Isae. 1.29; Lys. 9.4; Dem. 18.126, 19.314, 21.41, 61, 128 (twice), 134, 186 and 199, 23.130, 25.51-2 (twice) and 76-7 (twice), 29.3, 54.17, 58.29 and 62; Aeschin. 1.51 (twice); Hyp. 3.23; Din. 2.8.

${ }^{61}$ For detailed comparison of these procedures, see Fisher 1992: 36-85 and MacDowell 1978: 129-32.
} 
are attempts to arouse goodwill, ${ }^{62}$ and likewise statements that the opponent is not kosmios seek to deny it to them. ${ }^{63}$

One such claim occurs in this passage, which - as we shall see - contains several goodwillinducing tropes:

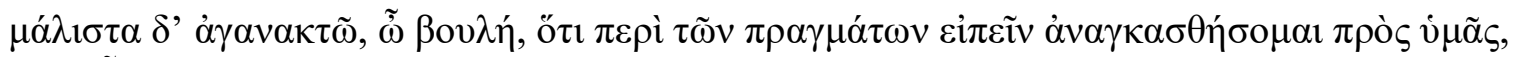

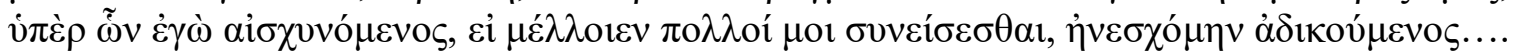

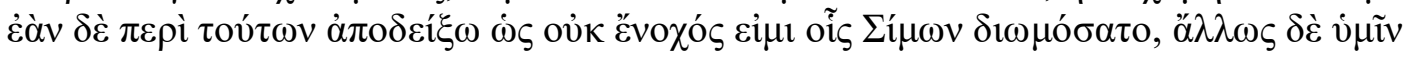

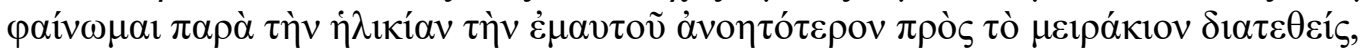

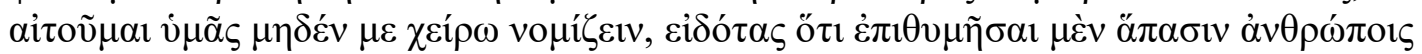

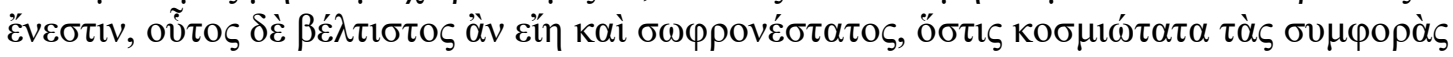

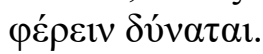

I am particularly upset, members of the Council, at being forced to speak about matters like this in front of you. I put up with mistreatment, because I was ashamed (aischunomenos) at the prospect of many people knowing all about me... But if I can show I am not guilty of any of the charges that Simon has stated on oath, even though it is obvious that I have behaved rather foolishly (anoêtoteron) towards the young man, given my age, I shall ask you to think no worse of me. You know that desire affects everybody and that the best and most restrained (sôphrôn) man is the one who can bear his troubles in the most orderly manner (kosmiôtata). ${ }^{64}$

We have already seen that kosmiotês encourages goodwill. It is linked here to being restrained (sôphrôn), i.e. having good self-control (sôphrosunê; cf. Isoc. 7.37 above, and Aristotle's virtues). Isocrates says that sôphrosunê leads to other goods (8.199), that Athenian ancestors liked sôphrosunê and were themselves sôphrones (7.37-8), and that people should be punished to make them more sôphrones (7.13). Demosthenes believes the qualities that inspire most admiration are courage, justice, and moderation (18.215). Aeschines says a democrat should be both sôphrôn and metrios (3.170), and that aspiring politicians should adopt a sôphrôn way of life (3.249). We also hear that defendants rely on arguing that they are metrioi and sopphrones to win pity (eleos) and kindly feelings (philanthrôpia - similar to eunoia; [Dem.] 25.76). All this suggests again that arguing one is sôphrôn is likely to arouse eunoia in the jury, ${ }^{65}$ or that arguing the opponent is not aims at suppressing eunoia for him. ${ }^{66}$

In the excerpt above, the speaker claims to feel shame. A sense of shame in appropriate circumstances is included in the virtues by Aristotle (Eth. Nic. 4.9), and elsewhere he refers to shamelessness as a vice $(2.6,1107 \mathrm{a} 9-11)$. A lawcourt speech too includes aischunê in a list of virtues alongside sôphrosunê and eutaxia (similar to eukosmia; [Dem.] 25.4). The close proximity of several character arguments in this part of Lys. 3 (after the above excerpt he portrays the opponent as angry, arrogant, drunken, and behaving inappropriately to women which will arouse hostility towards him) is strong evidence that this confession of shame, at

\footnotetext{
${ }^{62}$ Isoc. 18.18 and 43, 15.24, 144 and 162; Isae. 4.27, 10.25; Lys. 3.4, 7.41, 12.20, 16.18, 21.19, 26.3.

${ }^{63}$ Lys. 1.26, 14.29 and 41; Dem. 39.14; [Dem.] 59.51; Aeschin. 1.189, 3.4 (by inference).

${ }^{64}$ Tr. Todd 2000: 44-5, slightly modified.

${ }^{65}$ See Antiph. 4.2.1 and 4.3.2; Isoc. 15.24 (so far rhetorical exercises, not genuine speeches); Lys. 3.4, 21.19; Aeschin. 2.4.

${ }^{66}$ Antiph. 4.4.2; [Dem.] 25.77
} 
acting in a way men of his age should not, ${ }^{67}$ is intended as another character trait, and another bid for jurors' goodwill. We find several confessions of shame in the corpus, ${ }^{68}$ all of which may similarly be intended to arouse goodwill.

Finally, in the above excerpt, we can note one more feature: the speaker's admission of foolishness (repeated at $\S \S 9,31$ ). This is not obviously a virtue, but we can note that the opposite trait (being deinos) seems to arouse hostility in Demosthenes' Against Lakritos, ${ }^{69}$ with the speaker seeming to court goodwill through his own self-characterization of ill-educated, bluff, but honest, rustic simplicity. And we might also note Euphiletos's admission of behaving in a simpleminded way (Lys. 1.10: '̇ं another celebrated Lysianic character portrayal.

There is no need to examine every virtue on Aristotle's list, but one other requires brief consideration here, not least because of the importance he attaches to it, and that is courage. We can note that Aeschines includes it within the important qualities of the democrat (3.170). Demosthenes asserts (in a deliberative speech) that speakers typically dissuade support from a proposal in the Assembly by saying that the speaker is cowardly (8.68) - i.e. 'playing the man, not the ball'. He goes on to argue that his own proposals show his personal bravery (8.69). Andocides, proposing his recall from exile, says that his services to the city (even while exiled) show that he dared to risk even more than generals (Andoc. 2.18); and an alleged supporter of the oligarchy says he chose to face danger when others evaded it (Lys. 16.17) - both comments clearly seeking to arouse goodwill. Aeschines, by contrast, tries to persuade jurors that Demosthenes is a self-admitted coward (3.175), thus surely seeking to deny it to him.

Aside from claiming a virtuous character trait, there is another way a speaker can demonstrate good character: by detailing his past actions and way of life. This occurs in a number of speeches. A clear indication of what this is intended to convey occurs towards the end of Hyperides' In Defense of Lykophron. The speaker tells the jury to base their judgment on a review of his entire life since the past is his most reliable character witness (1.14: $\dot{v} \mu \tilde{\alpha} \varsigma \delta$ ' oĩ $\mu \alpha 1$

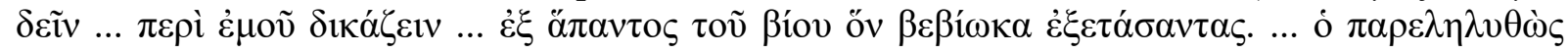

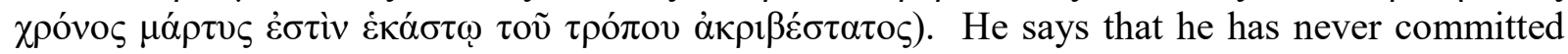

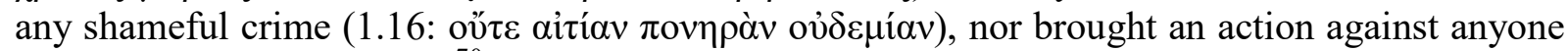
(i.e. he is not a sykophant) ${ }^{70}$ - both claims being routinely made in Attic speeches and clearly intended to gain goodwill. He says he has spent his entire life breeding horses - an activity, associated with the aristocratic rich, that could alienate the jury - but he more than negates this by saying he was awarded crowns for bravery (a virtue attracting goodwill) in his cavalry service, was elected Phylarch then Hipparch for Lemnos twice (showing he was admired, and popular in democratic elections), ${ }^{71}$ volunteered to serve for a third year, was never prosecuted during his service (prosecutions of public officials were commonplace) and was crowned a

\footnotetext{
${ }^{67}$ Per Aristotle, the young are incontinent in erôs (Rh. 2.12, 1389a3-6), but older men are not (Rh. 2.13, 1390a12-13; 2.14, 1390b2-3). On the speaker's embarrassment, see Todd 2007: 278.

${ }^{68}$ Isoc. 16.3; Lys. 3.3, 6 and 9, 5.3; Isae. 1.39.

${ }^{69}$ See Sanders 2012: 373-4, which discusses Dem. 35.39-43, a virulent attack on speakers who use their sophistic education to bamboozle jurors.

${ }^{70}$ Someone who regularly prosecuted people under the ho boulomenos rules (see note 27), for their own monetary enrichment. For a brief discussion - including how they aroused hostility - and bibliography, see Sanders 2012: 370-2.

${ }^{71}$ The ten Phylarchs were leaders of the cavalry for each of the ten Athenian tribes. The two Hipparchs were overall heads of the cavalry, and one commanded in Lemnos which was under Athenian control. See further Cooper 2001: 77 n. 28 .
} 
further three times (1.17-18). All these actions and achievements are clearly intended to be marks of good character: he concludes this section by saying that it is impossible for the man of

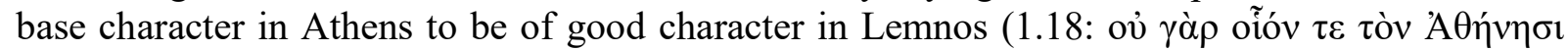

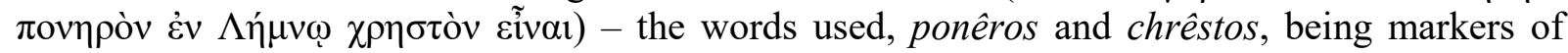
base and good character respectively.

Lysias's For Mantitheus also involves an aristocrat, with much weaker democratic credentials (he was suspected of supporting the Thirty, a bloody oligarchic regime), resorting to character portrayal by describing his past actions. Though he claims to have inherited little, he dowered his sisters handsomely, and gave his brother more than half what remained (16.10). Looking after aged or female family members and not squandering one's patrimony are frequently mentioned in speeches as praiseworthy and their opposite as censurable, so these are relevant points for a character portrait. In his daily life he claims decorous conduct (16.11: epieikeia): he is hated by those who drink or dice, and has never been prosecuted by private suit, public suit, or impeachment (16.12) - a more comprehensive claim than Lykophon's. He chose to serve in the infantry rather than the cavalry $(16.13)$ - a statement having political overtones, ${ }^{72}$ and testifying to his courage (a virtue/goodwill trait) as the infantry had a higher casualty rate details he states explicitly. He defrayed others' military expenses (16.14), had himself posted to the front rank (16.15; i.e. the most dangerous place), and volunteered rather than showing cowardice (16.16); thus he was zealous (prothumos) and dared to face danger (16.17) - goodwill traits we have seen before. He concludes by saying he should be judged for such things (16.18:

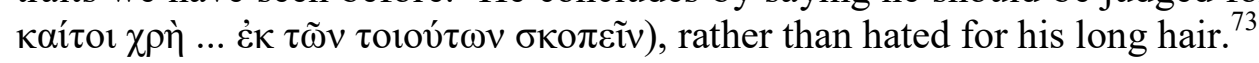

One final case is noteworthy, Lysias's On the Property of Aristophanes, which again concludes with a character portrait - not of the speaker (beyond denying involvement in legal proceedings), but of his father. He lists his father's liturgies which totaled a huge sum (19.57$9),{ }^{74}$ and adds that on top of this he privately chose to help some of the poorer citizens dower their daughters and sisters, ransomed others from enemies, and helped still others with burial costs (19.59). While helping jurors personally (through liturgy performance) will win their gratitude, freely helping other citizens on this scale should arouse jurors' goodwill. ${ }^{75}$ And indeed the speaker claims that his father considered all these people his philoi, a call for his fellow citizens' friendship in return.

\section{Conclusion}

Pseudo-Aristotle's Rhetoric to Alexander accords arousing jurors' goodwill a significant role in forensic argumentation, referring to it by a variety of terms (though not eunoia, which appears regularly in the Attic corpus). Aristotle, whose Rhetoric discusses friendship (philia/to philein), seems to agree. While Aristotle sees conceptual differences between philia and eunoia - which is possibly closer to his to philein - these are not reflected in the Attic corpus. There we see overlapping but diverging patterns of use of the two words. Orators sometimes explicitly request

\footnotetext{
${ }^{72}$ Most who kept horses were rich aristocrats, suspected of oligarchic leanings. Mantitheus implies he did not side with the aristocrats against the dêmos.

${ }^{73}$ A fashion, imitating the Spartan elite, popular among the Athenian aristocracy.

${ }^{74}$ Generous liturgy performance attracting gratitude - note 54 above.

${ }^{75}$ Arist. Rh. 2.4.1381a11-13: 'Again, we feel friendly to those who have treated us well, either ourselves or those we care for; or if they have done so on a large scale, or readily, or at some particular crisis; provided it was for our

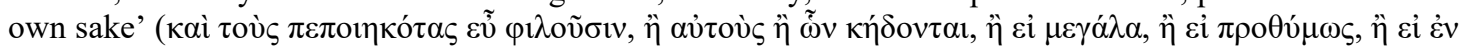

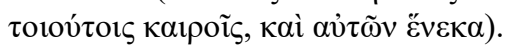


eunoia, normally in the prologues of their speeches, but there appear to be patterns in which types of speech (public/private, prosecution/defense) or legal case see these requests. Reasons for some of these patterns were confidently stated, others more speculatively offered.

Beyond explicitly requesting eunoia, orators also regularly protest their eunoia or philia for the city, which I argued aims to prompt reciprocal good feeling from the jury. More wide-ranging are covert attempts to arouse goodwill/friendliness, which do not mention either of these Greek words explicitly. They can be prompted through claims of a variety of good character traits (e.g. metriotês, kosmiotês, sôphrosunê, andreia, a proper sense of shame), or through a description of the speaker's past actions and way of life, including evidence of goodwill previously shown towards the dêmos or strenuous efforts on the city's behalf, and private, gratuitous, large-scale generosity to fellow citizens.

\section{Bibliography}

Allen, D. S. 2000. The World of Prometheus: The Politics of Punishing in Democratic Athens. Princeton and Oxford.

Allen, D. S. 2003. 'Angry Bees, Wasps, and Jurors: The Symbolic Politics of ỏ $p \gamma \eta$ in Athens'. In S. Braund and G. W. Most. eds. Ancient Anger: Perspectives from Homer to Galen. Cambridge. 76-98

Bers, V. 2009. Genos dikanikon: Amateur and Professional Speech in the Courtrooms of Classical Athens. Cambridge, MA and London.

Cairns, D. L. 2003. 'The Politics of Envy: Envy and Equality in Ancient Greece'. In D. Konstan and N. K. Rutter. eds. Envy, Spite and Jealousy: The Rivalrous Emotions in Ancient Greece. Edinburgh. 235-52

Carey, C. 1996. 'Rhetorical Means of Persuasion'. In A. O. Rorty. ed. Essays on Aristotle's 'Rhetoric'. Berkeley, Los Angeles and London. 399-415

Chiron, P. 2002. Rhétorique à Alexandre. Paris.

Chiron, P. 2011. 'Lecture rhétorique du prooimion de Daphnis et Chloé'. In R. Poignault. ed. Présence du roman grec et latin. Clermont-Ferrand. 255-66

Cooper, C. R. 2001. 'Hyperides'. In I. Worthington, C. R. Cooper and E. M. Harris. trs. Dinarchus, Hyperides, and Lycurgus. Austin. 59-151

De Brauw, M. 2010. 'The Parts of the Speech'. In I. Worthington. ed. A Companion to Greek Rhetoric. Malden, MA and Oxford. 187-202

De Romilly. 1958. 'Eunoia in Isocrates or the Political Importance of Creating Good Will'. Journal of Hellenic Studies 78, 92-101

Earl, D. 1972. 'Prologue-form in Ancient Historiography'. In H. Temporini. ed. Aufstieg und Niedergang der römischen Welt, Vol. I.2. Berlin and New York. 842-56

Fisher, N. R. E. 1992. Hybris: A Study in the Values of Honour and Shame in Ancient Greece. Warminster.

Fisher, N. R. E. 2003. 'Let Envy be Absent: Envy, Liturgies and Reciprocity in Athens'. In D. Konstan and N. K. Rutter. eds. Envy, Spite and Jealousy: The Rivalrous Emotions in Ancient Greece. Edinburgh. 181-215

Forster, E. S. 1984. 'Rhetoric to Alexander'. In J. Barnes. ed. The Complete Works of Aristotle. Princeton. 2270-315

Fortenbaugh, W. W. 1988. 'Cicero's De oratore 2.178-216'. Rhetorica 6, 259-73 
Foxhall, L. 1998. 'The Politics of Affection: Emotional Attachments in Athenian Society'. In P. Cartledge, P. Millett, and S. von Reden. eds. KOSMOS: Essays in Order, Conflict, and Community in Classical Athens. Cambridge. 52-67

Goldberg, S. M. 1983. 'Terence, Cato, and the Rhetorical Prologue'. Classical Philology 78, 198-211

Hadreas, P. 1995. 'Aristotle on the Beginning of Friendship'. Ancient Philosophy 15.2, 393-402

Herman, G. 1987. Ritualised Friendship and the Greek City. Cambridge.

Irwin, T. 1999. Aristotle: 'Nicomachean Ethics'. Indianapolis and Cambridge.

Isager, S. and M. H. Hansen. 1975. Aspects of Athenian Society in the Fourth Century B.C.: A Historical Introduction to and Commentary on the paragraphe-Speeches and the 'Speech against Dionysodorus' in the Corpus Demosthenicum. xxxii-xxxviii and lvi. Odense.

Johnstone, S. 1999. Disputes and Democracy: The Consequences of Litigation in Ancient Athens. Austin.

Kennedy, G. A. 2007. Aristotle, 'On Rhetoric': A Theory of Civic Discourse. New York and Oxford.

Konstan, D. 1997. Friendship in the Classical World. Cambridge.

Konstan, D. 2006. The Emotions of the Ancient Greeks: Studies in Aristotle and Classical Literature. Toronto, Buffalo and London.

Kurihara, A. 2003. 'Personal Enmity as a Motivation in Forensic Speeches'. Classical Quarterly 53, 464-77

MacDowell, D. M. 1978. The Law in Classical Athens. Ithaca.

Mitchell, L. 1997. Greek Bearing Gifts: The Public Use of Private Relationships in the Greek World 435-323 BC. Cambridge.

Ober, J. 1989. Mass and Elite in Democratic Athens: Rhetoric, Ideology, and the Power of the People. Princeton.

Price, A. W. 1989. Love and Friendship in Plato and Aristotle. Oxford.

Rhys Roberts, W. 1984. 'Rhetoric'. In J. Barnes. ed. The Complete Works of Aristotle. Princeton. 2152-269

Rubinstein, L. 2000. Litigation and Cooperation: Supporting Speakers in the Courts of Classical Athens. Stuttgart.

Rubinstein, L. 2004. 'Stirring up Dicastic Anger'. In D. L. Cairns and R. A. Knox. eds. Law, Rhetoric, and Comedy in Classical Athens: Essays in Honour of Douglas M. MacDowell. Swansea. 187-203

Rubinstein, L. 2014. 'Evoking Anger through Pity: Portraits of the Vulnerable and Defenceless in Attic Oratory'. In A. Chaniotis and P. Ducrey. eds. Unveiling Emotions II: Emotions in Greece and Rome: Texts, Images, Material Culture. Stuttgart. 135-65

Sanders, E. 2012. 'He is a Liar, a Bounder, and a Cad': The Arousal of Hostile Emotions in Attic Forensic Oratory'. In A. Chaniotis. ed. Unveiling Emotions: Sources and Methods for the Study of Emotions in the Greek World. Stuttgart. 359-87

Sanders, E. 2014. Envy and Jealousy in Classical Athens: A Socio-psychological Approach. New York.

Sanders, E. forthcoming. 'Persuasion through Emotions in Deliberative Oratory'. In E. Sanders and M. Johncock. eds. Emotion and Persuasion in cCassical Antiquity. Stuttgart.

Todd, S. C. 1993. The Shape of Athenian law. Oxford.

Todd, S. C. 2000. Lysias. Austin.

Todd, S. C. 2007. A Commentary on Lysias: Speeches 1-11. Oxford. 
Usher, S. 1999. Greek Oratory: Tradition and Originality. Oxford. 